\title{
Analysis of The Influence of Audit Committee, Sharia Supervisory Board, and Islamic Work Ethic on The Quality of Sharia Bank Financial Statements in Indonesia
}

\author{
Iwan Budiyono1, Chansera Kista Sabilla ${ }^{2}$ \\ 1,2,3 Politeknik Negeri Semarang, Semarang, Indonesia. \\ serasabilla@gmail.com
}

\begin{abstract}
Purpose - This study aims to analyze the influence of audit committees, sharia supervisory boards, and Islamic work ethic on the quality of islamic bank financial statements in Indonesia.

Method-Themethod in this study used Multiple Linear Regression Analysis with SPSS software tools.

Result - Based on the results of this research, simultaneously the audit committee, sharia supervisory board, and Islamic work ethic have a significant influence on the quality of islamic bank financial statements in Indonesia. Meanwhile, in part, the audit committee and islamic work ethic have no significant effect on the quality of islamic bank financial statements in Indonesia. SSB partially affects the quality of islamic bank financial statements in Indonesia.

Implication-Thisstudy uses the data from Islamic bankfinancial statement in Indonesia, audit committees, sharia supervisory boards, Islamic work ethic.

Originality - The data was taken with the dissemination of questionnaires distributed to 30 respondents. The respondents were a reflection of the members of the audit committee and SSB who were qualified as students of shariabanking polytechnicstate of semarangwho hadreceived islamicbank audit courses.
\end{abstract}

Keywords: $\quad$ Audit Committee, SSB, Islamic Work Ethic, and Quality of Sharia Bank Financial Statements. 
Iwan Budiyono, Chansera Kista Sabilla

\section{Introduction}

We already know that sharia banks are banking institutions based on the principle of using Islamic law or in accordance with the Quran and hadith, fatwa DSN MUI. Just like with Islam, which regulates all provisions both in daily life and financial institutions must be in accordance with sharia principles. Sharia banks are required to have Sharia Supervisory Board or abbreviated as SSB (Briston, 1986). Sharia Supervisory Board itself aims to justify the operational suitability of Sharia banks have fulfilled sharia principles or not. Thus, the characteristics of Sharia banks with conventional banks are certainly different. And this also greatly impacted financial reporting practices (Kamel \& Maurice, 1997). In profit management banking is very important because the cases of profit management in banking are the most frequent cases. Such as on the manipulation of income through the provision of loan losses in the banking sector. Why in the bank the problem of profit management is greater due to high leverage and bank managers take more risks because they rely heavily on depositors and central banks in terms of funding. As revealed by (Beatty et al., 2002) which revealed that sharia banks as well as conventional banks use loan loss provision to absorb the estimated credit loss that is the most important business activity. No wonder that the financial reporting of banks must produce financial statements with good quality to avoid the problem of allowance for losses on loans.

Cases concerning financial reporting problems in banks, not only occurred abroad, but in Indonesia this case occurred in several Sharia banks such as the case of embezzlement of savings at Bank Muamalat Mataram branch. The case involves one of the employees working in the marketing department of Bank Muamalat Mataram branch intentionally not recording the customer's financial transactions into the bank's financial statements. From this case, the bank suffered a loss of Rp 9 billion. And there is also a fraud case that occurred at Bank Syariah Mandiri Bogor branch involving three internal bank officials, the fraud is related to the break-in of funds through fictitious financing at Bank Syariah Mandiri bogor branch amounting to 102 billion rupiah to 197 fictitious customers. As a result of the lending, Bank Syariah Mandiri has the potential to 
lose 59 billion rupiah (Rajhi \& Hassairi, 2011). And other cases of fraud. Thus, not only sharia supervisory board that seeks to check sharia bank financial statements, but the function of the board of commissioners, one of which is the Audit Committee is needed in terms of financial reporting.

The performance of the audit committee in monitoring the financial statements process is also examined by (Klein, 2002); (Felo et al., 2005); (Xie et al., 2003); (Abbott et al., 2004); (Chtourou \& Courteau, 2004); (Persons, 2005);(Lin et al., 2006). They suggest the audit committee has an influence on the quality of financial statements. The role of the audit committee is also a mechanism in corporate governance in terms of improving the effectiveness of internal controls for financial reporting (Elbannan, 2009). In addition to the role of the audit committee and the Sharia Supervisory Board in monitoring the financial statements of these results will not be maximal if in the work they do not apply the work ethic of Islam. The preparation in Sharia financial reporting is basically what needs to be improved is the application of Islamic work ethic. Because, in working, islamic ethical institutions will affect human resources so that the preparation of Islamic financial statements will be produced quality preparation. This is in line with research conducted by Sudirman (2017) that the islamic work ethic has a positive and significant effect on the quality of accounting report presentation.

Based on the business phenomenon above, therefore this research aims to find out the influence of the audit committee, sharia supervisory board, and Islamic work ethic whether it has a significant influence on the quality of Islamic bank financial statements. Therefore, this research is expected to contribute to Sharia banks in solving problems regarding financial reporting, as well as providing insight into the role and function of the audit committee, $\mathrm{SSB}$, and Islamic work ethic. 
Iwan Budiyono, Chansera Kista Sabilla

\section{Literature Review}

\section{Quality of Financial Statements}

Financial Statements are reports that are used as a source of information that the users of financial statements trust in looking at management performance, as well as how the company's financial performance or financial position. In Sharia banks, these financial statements are very useful in terms of providing the right profit share for customers both funding customers and customers who receive financing. Looking at the research conducted by (Rini, 2014) that quality financial statements must be in accordance with applicable accounting standards and must comply with all existing regulations. Quality financial statements are not only obtained from the preparation of financial statements but must work with other parties in order to help and maintain the quality of financial statements (Rini, 2014). In the concept of quality financial reporting researched by (Miller \& Bahnson, 1999) the concept of financial statements is projected in a timely, reasonable manner, as well as complete disclosure of information.

\section{Audit Committee}

Groups that are independent and have absolutely no interest in management are then appointed because they have views, especially in the field of accounting and matters relating to internal control in a company, especially in the banking sector, called the Audit Committee (Sukartha \& Swingly, 2015). The Audit Committee was formed through a decision of the Board of Commissioners. So that the Audit Committee is fully responsible to the Board of Commissioners. The role of the Audit Committee itself in monitoring financial reporting is closely related to how the quality of the financial reports produced. This is in line with previous researchers conducted by (Nashwa, 2003) that the quality of the resulting financial reports was detected poorly due to the failure of the role of the Audit Committee in monitoring the financial reporting process. So it is very necessary in every company to have an Audit Committee that is competent in carrying out its 
responsibilities. To ensure quality financial reports, an Audit Committee that is competent in carrying out its functions and responsibilities is required. This is in line with research conducted by (McMullen et al., 1996) which found that there is a relationship between the existence of an audit committee and the quality of financial reporting as measured by 5 factors such as shareholder litigation accusing fraud, reported earnings correction, SEC enforcement actions. , illegal acts, or auditor changes involving disagreements between clients and auditors. The Audit Committee has a significant positive effect on the quality of financial statements. This opinion has been researched by (Pomeroy \& Thornton, 2008); (Chen et al., 2007); (Labelle et al., 2010) which suggests there is an influence between the Audit Committee and the quality of financial reports.

\section{Sharia Supervisory Board}

SSB within sharia banks is used to ensure that all sharia bank operations are in accordance with sharia principles, and comply with all applicable Islamic laws (Abdelsalam et al., 2016). The role of SSB as well as the prevailing sharia law provisions are expected to improve the quality of financial statements so that things such as cheating in manipulating profit management do not occur. In addition, SSB has a function in internal audit procedures, always ensuring that sharia bank managers are always guided by sharia law. (Briston, 1986) revealed that SSB has 3 functions, namely: providing advice, performance supervision, and auditing in zakat funds. Meanwhile, according to (Azhar Rosly, 2010) SSB supervises sharia banking operations in accordance with sharia maqasid objectives. SSB most important responsibility is to monitor internal control in sharia. This is supported by (Wajdi Dusuki, 2008) So SSB plays a role in monitoring the quality of financial reporting passively.

\section{Islamic Work Ethic}

The word ethos comes from the Greek meaning attitude, personality, character, and character. The ethos is shaped by the habits, culture, and value system it believes in. The word ethos is also known as ethics, etiquette, which 
Iwan Budiyono, Chansera Kista Sabilla

contains the definition or meaning of spirit in doing something so that the results are optimal, and avoid any failure or damage. Therefore, his work can avoid or eliminate defects from his work (Rahmadieni, 2019). In the research conducted by rahmadieni (2019) suggested that the better psak will be the better the quality of presentation of financial statements produced. Thus, the work ethic of Islam has a positive and significant effect on the quality of presentation of Islamic financial statements (Rahmadieni, 2019).

\section{Methods}

In this study using primary data used related to respondents' answers directly from questionnaires on 5 attributes of the role of the audit committee (Tengamnuay \& Stapleton, 2009),10 attributes of the role of sharia supervisory board (Garas \& Pierce, 2010); Bank Indonesia Regulation No.12 / 13 / DPbS 2010) and 9 attributes of financial reporting quality (Jonas \& Blanchet, 2000). So the total attributes in the questionnaire amounted to 30. The collection of questionnaires is calculated on a likert scale of 5 points from statement 1 stating disagree to 5 that express strongly agree. The questionnaire was distributed or distributed to respondents who were a reflection of the members of the audit committee and SSB who were qualified as sharia banking students of Semarang State Polytechnic who had received Islamic Bank Audit courses. Analysis tools in the process of data processing in this study using Multiple Regression Analysis with SPSS Software. Then tested is, Preliminary test contains data quality test (validity and reliability) and Test analysis using coefficient of determination test, $\mathrm{F}$ test and t test.

\section{Results and Discussion}

All questionnaires were distributed privately to 30 respondents. The respondents were a reflection of the members of the audit committee and SSB who were qualified as students of Sharia banking Polytechnic State of Semarang who had received islamic bank audit courses. This research uses analysis tools in the form of SPSS software, and then explains some of the results. On the data quality test (validity and reliability), the entire questionnaire met the requirements due to $r$ calculate $>r$ table $=0.3610$ and 
Cronbach's Alpha value was greater than 0.6 . Then described the results on the coefficient of determination test, $F$ test, and t test. In the results of the coefficient of determination test shows that this model explains the role of the audit committee and sharia supervisory board and islamic work ethic describes the quality of financial reporting by $38.7 \%$. While $61.3 \%$ is described by other variables such as: effectiveness of internal control over financial reporting, the role of internal auditors, management commitments, and corporate governance. Then for the $\mathrm{F}$ test results showed that the role of the audit committee, sharia supervisory board, and islamic work ethic simultaneously influenced the quality of financial reporting, indicated by the sign $0.001<$ 0.005 .

Then, in the t test results, seen from the t calculate, which has a relationship partially affecting the quality of financial statements SSB only, seen from $t$ count $=1.708>1.70562$ t table.

In sharia banks, in order to realize quality financial reporting, the audit committee and sharia supervisory board need to cooperate and be responsible in carrying out their roles related to the quality of financial reporting. As in QS. Al-Maidah: 2 which states that we fellow human beings are obliged to be together or help each other in doing good and piety

"And do not hate any people because they hinder you from the Sacred Mosque and encourage you to wrong them. And help you in righteousness and piety, and do not help in sin and transgression. And fear Allah."

\section{Table 1. ANOVA}

\begin{tabular}{ccccccc}
\hline & Model & Sum of Squares & df & Mean Square & f & Sig. \\
\hline $\mathbf{1}$ & Regression & 127.017 & 3 & 42.339 & 7.109 &, 001 \\
& Residual & 154.850 & 26 & 5.956 & & \\
& Total & 281.867 & 29 & & & \\
\hline
\end{tabular}

a. Dependent Variable: KUALITAS_LAP_KEUANGAN

b. Predictors: (Constant), ETOS_KERJA_ISLAM, KOMITE_AUDIT, DPS 
Iwan Budiyono, Chansera Kista Sabilla

Sharia banking theory put forward by Algoud \& Lewis (1999), sharia supervisory board is the center of corporate governance framework at Islamic Bank. This supports (Azhar Rosly, 2010) which presents the role of SSB that activates sharia principles or sharia maqashid and monitors how contract transactions in Sharia banking take place, will affect the quality in financial reporting. This is in line with (Briston, 1986) which implies that sharia supervisory board has a passive role in controlling the quality of financial reporting. Previous researchers have also found that the role of sharia supervisor dean is very important in supporting the quality of Islamic bank financial statements (Wajdi Dusuki, 2008); (Rini, 2014). If the Sharia supervisory board is not responsible in carrying out its role, then in the bank there will be transactions that are certainly not in accordance with sharia principles.

\section{Conclusion}

This research was prepared to determine the influence of variable audit committees, Sharia supervisory boards, and Islamic work ethic on the quality of Islamic bank financial statements in Indonesia. This data source comes from primary data with the dissemination of questionnaires as many as 30 respondents. The conclusions in this study suggest that the audit committee, sharia supervisory board, and Islamic work ethic simultaneously have a significant influence on the quality of islamic bank financial statements in Indonesia. While in the t test or partial hypothesis test, the audit committee and islamic work ethic partially had no significant effect on the quality of islamic bank financial statements in Indonesia. Meanwhile, in sharia supervisory board variables, it is produced that it partially affects the quality of islamic bank financial statements in Indonesia.

The implications of this research are the strengthening of cooperation or role between the audit committee, sharia supervisory board, and Islamic work ethic to control strictly that transactions conducted in Sharia banks are in accordance with sharia principles and also honesty from various parties in Sharia banks. This study only covers these variables, not covering other 
variables related to the quality of financial statements. Therefore, the limitations in this study are due to only testing the variables of the audit committee, SSB, and Islamic work ethic on the quality of Islamic bank financial statements in Indonesia, as well as other limitations such as in this study in no way using secondary data, and the existence of several indicators in the

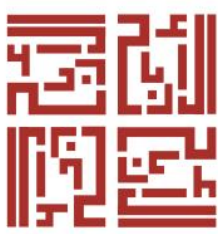
questionnaire that do not meet the requirements.

Therefore, further research can explore other variables such as the effectiveness of internal control over financial reporting, the role of internal auditors, and management.

\section{References}

Abbott, L. J., Parker, S., \& Peters, G. F. (2004). Audit committee characteristics and restatements. Auditing, 23(1), 69-87. https://doi.org/10.2308/aud.2004.23.1.69

Abdelsalam, O., Dimitropoulos, P., Elnahass, M., \& Leventis, S. (2016). Earnings management behaviors under different monitoring mechanisms: The case of Islamic and conventional banks. Journal of Economic Behavior and Organization, 132, 155-173. https://doi.org/10.1016/j.jebo.2016.04.022

Azhar Rosly, S. (2010). Shariah parameters reconsidered. International Journal of Islamic and Middle Eastern Finance and Management. https://doi.org/10.1108/17538391011054372

Beatty, A. L., Ke, B., \& Petroni, K. R. (2002). Earnings management to avoid earnings declines across publicly and privately held banks. Accounting Review. https://doi.org/10.2308/accr.2002.77.3.547

Briston, R. \& E.-A. A. (1986). Religious audit: could it happen here? Accountancy.

Chen, S., Shevlin, T., \& Tong, Y. H. (2007). Does the pricing of financial reporting quality change around dividend changes? Journal of Accounting Research. https://doi.org/10.1111/j.1475679X.2007.00225.x 
Iwan Budiyono, Chansera Kista Sabilla

Chtourou, S. M., \& Courteau, L. (2004). Independence, and Activity on. Practice, 23(2), 13-35.

Elbannan, M. A. (2009). Quality of internal control over financial reporting, corporate governance and credit ratings. International Journal of Disclosure and Governance. https://doi.org/10.1057/jdg.2008.32

Felo, A. J., Krishnamurthy, S., \& Solieri, S. A. (2005). Audit Committee Characteristics and the Perceived Quality of Financial Reporting: An Empirical Analysis. SSRN Electronic Journal. https://doi.org/10.2139/ssrn.401240

Garas, S. N., \& Pierce, C. (2010). Shari'a supervision of Islamic financial institutions. Journal of Financial Regulation and Compliance. https://doi.org/10.1108/13581981011093695

Jonas, G. J., \& Blanchet, J. (2000). Assessing quality of financial reporting. In Accounting

Horizons. https://doi.org/10.2308/acch.2000.14.3.353

Kamel, N., \& Maurice, P. (1997). THE INFLUENCE OF ISLAM ON BANK FINANCIAL REPORTING. International Journal of Commerce and Management, 7(2), 56-83. https://doi.org/10.1108/eb047349

Klein, A. (2002). Audit committee, board of director characteristics, and earnings management. Journal of Accounting and Economics. https://doi.org/10.1016/S0165-4101(02)00059-9

Labelle, R., Gargouri, R. M., \& Francoeur, C. (2010). Ethics, diversity management, and financial reporting quality. Journal of Business Ethics. https://doi.org/10.1007/s10551-009-0225-7

Lin, J. W., Li, J. F., \& Yang, J. S. (2006). The effect of audit committee performance on earnings quality. Managerial Auditing Journal, 21(9), 921-933. https://doi.org/10.1108/02686900610705019

McMullen, D. A., Raghunandan, K., \& Rama, D. V. (1996). Internal control reports and financial reporting problems. Accounting Horizons. 
Miller, P. B., \& Bahnson, P. R. (1999). Quality financial reporting: Why you need it and how to implement it. Journal of Corporate Accounting \& Finance. https://doi.org/10.1002/(sici)10970053(199923)11:1<83::aid-jcaf7>3.0.co;2-w

Nashwa, G. (2003). AUDIT COMMITTEES: THE SOLUTION TO QUALITY FINANCIAL REPORTING? The CPA Journal.

Persons, 0. S. (2005). The Relation Between the New Corporate Governance Rules and the Likelihood of Financial Statement Fraud. In Review of Accounting and Finance. https://doi.org/10.1108/eb043426

Pomeroy, B., \& Thornton, D. B. (2008). Meta-analysis and the accounting literature: The case of audit committee independence and financial reporting quality. European Accounting Review, 17(2), 305-330. https://doi.org/10.1080/09638180701819832

Rahmadieni, R. Y. (2019). Faktor-Faktor Yang Mempengaruhi Kualitas Penyajian Laporan Keuangan Syariah Baitul Maal Wa Tamwil Di Kabupaten Wonogiri. Al-Mashrafiyah: Jurnal Ekonomi, Keuangan, Dan Perbankan Syariah. https://doi.org/10.24252/almashrafiyah.v3i2.10038

Rajhi, W., \& Hassairi, S. A. (2011). Unconventional Banking System in Distress. International Journal of Economics and Finance. https://doi.org/10.5539/ijef.v3n4p70

Rini, R. (2014). The effect of audit committee role and sharia supervisory board role on financial reporting quality at Islamic banks in Indonesia. Journal of Economics, Business, \& Accountancy Ventura, 17(1), 145. https://doi.org/10.14414/jebav.v17i1.273

Sukartha, I. M., \& Swingly, C. (2015). Pengaruh Karakter Eksekutif, Komite Audit, Ukuran Perusahaan, Leverage dan Sales Growth pada Tax Avoidance. E-Jurnal Akuntansi Universitas Udayana.

Tengamnuay, K., \& Stapleton, P. (2009). The role of the audit committee in Thailand: A mature monitoring mechanism or an evolving process? Journal of Management and Governance. https://doi.org/10.1007/s10997-008-9067-4 
Iwan Budiyono, Chansera Kista Sabilla

Wajdi Dusuki, A. (2008). Understanding the objectives of Islamic banking: a survey of stakeholders' perspectives. International Journal of Islamic and Middle Eastern Finance and Management. https://doi.org/10.1108/17538390810880982

Xie, B., Davidson, W. N., \& Dadalt, P. J. (2003). Earnings management and corporate governance: The role of the board and the audit committee. Journal of Corporate Finance. https://doi.org/10.1016/S0929-1199(02)00006-8. 